\title{
MAKNA PERSETUJUAN BERSAMA DPR DAN PRESIDEN DALAM PEMBENTUKAN UNDANG-UNDANG
}

\author{
Aris Arianto ${ }^{1}$, Afif Hasbullah' ${ }^{2}$, Sholihan ${ }^{3}$ \\ ${ }^{123}$ Universitas Islam Darul 'Ulum \\ ${ }^{1}$ lovedetector21@gmail.com, ${ }^{2}$ afif@unisda.ac.id, ${ }^{3}$ sholihan@unisda.ac.id
}

\begin{abstract}
The establishment of the Act must be approved by the President as stated in Article 20 of the 1945 Constitution paragraph (2). Interesting when Indonesia uses a presidential system with the separation of powers. However, in the formation of the Act involving the President. Article 20 paragraph (2) of the 1945 Constitution confirms the necessity of mutual agreement in the discussion and ratification of the Law. However, there are other assertions, namely that in Article 20 paragraph (5) of the 1945 Constitution, even without the President's signature, the Act can still be promulgated within 30 days of the Draft Law being discussed. Things like that can't just happen without a reason. Therefore, the writing of this study will look for the meaning of the agreement between the DPR and the President in the formation of the Law and how the legal politics of Article 20 paragraph (5) of the 1945 Constitution.

The writing of this study is focused on researching and searching for the meaning of mutual agreement and focusing on legal politics from Article 20 paragraph 5 of the 1945 Constitution. The research method in this writing is normative juridical. The results of the research can be concluded that the meaning of the joint agreement between the DPR and the President in the establishment of the Law is an agreement in determining the policy in the form of a Law which is a reflection of the principle of checks and balances. Legal politics Article 20 paragraph (5) of the 1945 Constitution is an affirmation of Article 20 paragraph (2) of the 1945 Constitution or can be called an affirmation of collective agreement.
\end{abstract}

Keywords: Mutual Agreement, Goverment, President

\begin{abstract}
ABSTRAK
Pembentukan Undang-Undang harus mendapatkan persetujuan dari Presiden seperti yang ditegaskan dalam Pasal 20 UUD NRI 1945 ayat (2). Menarik ketika Indonesia menggunakan sistem Presidensiil dengan pemisahan kekuasaan. Namun, dalam pembentukan Undang-Undang melibatkan Presiden.Pasal 20 ayat (2) UUD NRI 1945 menegaskan tentang keharusan adanya persetujuan bersama dalam pembahasan dan pengesahan Undang-Undang. Namun, terdapat penegasan lain yaitu dalam Pasal 20 ayat (5) UUD NRI 1945 walaupun tanpa tanda tangan Presiden Undang-Undang tetap dapat diundangkan dalam jangka waktu 30 hari semenjak Rancangan Undang-Undang dibahas. Hal seperti itu tidak mungkin terjadi begitu saja tanpa adanya sebuah alasan. Oleh karena itu, penulisan studi ini akan mencari apa makna dari persetujuan bersama DPR dan Presiden dalam pembentukan Undang-Undang dan bagaimana politik hukum dari Pasal 20 ayat (5) UUD NRI 1945.

Penulisan studi ini difokuskan untuk meneliti dan mencari makna dari persetujuan bersama dan fokus pada politik hukum dari Pasal 20 ayat 5 UUD NRI 1945.
\end{abstract}


Metode penelitian dalam penulisan ini adalah yuridis normatif. Pokok hasil penelitian dapat disimpulkan makna persetujuan bersama antara DPR dan Presiden dalam pembentukan Undang-Undang adalah sebuah kesepakatan dalam menentukan kebijakan berupa Undang-Undang merupakan cerminan dari prinsip checks and balances. Politik hukum Pasal 20 ayat (5) UUD NRI 1945 merupakan penegasan dari Pasal 20 ayat (2) UUD NRI 1945 atau bisa disebut dengan penegasan dari persetujuan bersama.

\section{Kata Kunci: Persetujuan Bersama, Pemerintah, Presiden}

\section{PENDAHULUAN}

Reformasi konstitusi atau Undang-Undang Dasar Negara Republik Indonesia 1945 yang selanjutnya disebut UUD NRI 1945 adalah sebuah peristiwa besar yang pernah terjadi di Indonesia sejak berakhirnya rezim orde baru. Hal tersebut didasari keinginan untuk menegakkan Negara hukum yang melindungi segenap bangsa Indonesia yang kemudian mendorong terjadinya amandemen UUD NRI 1945. Reformasi konsitusi merupakan suatu keniscayaan, hal ini karena tuntutan perkembangan demokrasi dan ketatanegaraan di Indonesia. Generasi sekarang tidak mungkin mengikat generasi yang akan datang, serta ketentuan dalam konstitusi dapat diubah sesuai dengan peradaban zaman untuk terciptanya sebuah keadilan. ${ }^{1}$

Setalah terjadinya reformasi konstitusi yang terjadi selama empat kali menghasilkan beberapa ketentuan baru diantaranya adalah pembentukan UndangUndang merupakan kewenangan lembaga Dewan Perwakilan Rakyat. Namun, pembentukan Undang-Undang juga harus mendapatkan persetujuan dari presiden seperti yang ditegaskan dalam Pasal 20 UUD NRI 1945 ayat (2). ${ }^{2}$ Menarik ketika Indonesia menggunakan sistem Presidensiil dengan pemisahan kekuasaan. Namun, dalam pembentukan Undang-Undang melibatkan Presiden.

Ketika Pasal 20 ayat (2) UUD NRI 1945 menegaskan tentang keharusan adanya persetujuan bersama dalam pembahasan dan pengesahan Undang-Undang. Namun, terdapat penegasan lain yaitu dalam Pasal 20 ayat (5) UUD NRI 1945 walaupun tanpa tanda tangan Presiden Undang-Undang tetap dapat diundangkan dalam jangka waktu 30 hari semenjak Rancangan Undang-Undang dibahas. Hal

\footnotetext{
1 Alwi Wahyudi, Hukum Tata Negara Indonesia Dalam Prespektif Pancasila Pasca Reformasi, Pustaka Pelajar, Yogyakarta, 2012, h. 201.

${ }^{2}$ Lihat Indonesia, UUD NRI 1945.
} 
seperti itu tidak mungkin terjadi begitu saja tanpa adanya sebuah alasan. Oleh karena itu, penulisan studi ini akan mencari apa makna dari persetujuan bersama DPR dan Presiden dalam pembentukan Undang-Undang dan bagaimana politik hukum dari Pasal 20 ayat (5) UUD NRI 1945.

\section{METODE PENELITIAN}

Metode penelitian merupakan unsur utama dalam mengembangkan ilmu. Agar dapat mengungkapkan kebenaran yang sistematis metodologis dan konsisten. Maka, perlu adanya penelitian karena itu adalah tujuan utamanya. Namun, kebenaran disini diartikan sebagai kebenaran tentang pengetahuan teori. ${ }^{3}$ Metode penelitian memiliki beberapa kategori diantaranya adalah metode penelitian normatif, metode penelitian empiris dan metode penelitian normatif-empiris

Oleh karena penelitian merupakan sarana pengembangan ilmu pengetahuan untuk mencari kebenaran dan objek ilmu hukum merupakan hukum. ${ }^{4}$ maka metode penelitian yang digunakan harus sesuai dengan ilmu pengetahuan yang menjadi latar belakangnya, sehubungan dengan penulisan studi yang akan dibuat adalah meninjau masalah hukum dari segi Undang-Undang. Maka, metode penelitian yang digunakan dalam penelitian ini yaitu metode penelitian hukum normatif.

Metode penelitian hukum normatif penelitian ini bisa disebut dengan penelitian doktriner ataupun kepustakaan, dikatakan seperti itu karena metode penelitian ini memanfaatkan bahan-bahan hukum sekunder dari perpustakaan serta bahan primer yaitu Peraturan Perundang-Undangan. Penelitian hukum normatif mengkaji hukum tertulis yang didasarkan pada aspek teori, aspek filosofi dan perbandingan, bahasa yang digunakan adalah bahasa hukum dan pengkajian dari berbagai Pasal yang mengikat dalam Undang-Undang.

\section{HASIL DAN PEMBAHASAN}

Pemahaman yang menjadi landasan dari pembentukan Undang-Undang serta makna itu sendiri dan lembaga yang mempunyai wewenang membentuk Undang-Undang sesuai dengan Pasal 20 UUD NRI 1945 yang menegaskan:

1. Dewan Perwakilan Rakyat memegang kekuasaan membentuk UndangUndang

\footnotetext{
${ }^{3}$ Peter Mahmud Marzuki, Penelitian Hukum, Kencana, Jakarta, 2005, h. 20.

${ }^{4}$ Ibid., h. 18.
} 
2. Setiap Rancangan Undang-Undang dibahas oleh Dewan Perwakilan Rakyat dan Presiden untuk mendapat persetujuan bersama

3. Jika Rancangan Undang-Undang itu tidak mendapat persetujuan bersama, Rancangan Undang-Undang itu tidak boleh diajukan lagi dalam persidangan Dewan Perwakilan Rakyat masa itu

4. Presiden mengesahkan Rancangan Undang-Undang yang telah disetujui bersama untuk menjadi Undang-Undang

5. Dalam hal Rancangan Undang-Undang yang telah disetujui bersama tersebut tidak disahkan oleh presiden dalam waktu tiga puluh hari semenjak Rancangan Undang-Undang tersebut disetujui, Rancangan Undang-Undang tersebut sah menjadi Undang-Undang dan wajib diundangkan.

Berdasarkan Pasal 20 UUD NRI 1945 kewenangan pembentukan UndangUndang ada pada Dewan Perwakilan Rakyat, hal ini sesuai dengan prinsip presidensiil yang ditegaskan dalam UUD NRI 1945 setelah amandemen dengan penggunaan sistem pemisahan kekuasaan seperti ide dari Montesqiueu dalam teori Trias Politica. Kewenangan untuk mengatur atau membuat aturan pada dasarnya merupakan domain dari lembaga legislatif, berdasarkan prinsip kedaulatan merupakan prinsip eksklusif para wakil rakyat yang berdaulat untuk menentukan suatu peraturan yang mengikat dan membatasi kebebasan setiap individu warga Negara. ${ }^{5}$ Hal ini yang kemudian mendorong perubahan UUD NRI 1945 yang sebelumnya dalam naskah asli Pasal 5 UUD NRI 1945 sebelum amandemen memberi kewenangan Presiden untuk membentuk Undang-Undang. Ketentuan dalam naskah asli bukan hanya sangat membingungkan tetapi mengandung anomali, Presiden disamping memegang dan menjalankan kekuasaan eksekutif, namun dalam naskah asli sekaligus menjalankan fungsi legislatif. ${ }^{6}$ Ketentuan naskah asli juga sangat mengendurkan hak inisiatif dari DPR serta kekuasaan Presiden menjadi sangat kuat, oleh karena itu kemudian wajar jika dilakukan amandemen dan kewenangan membentuk Undang-Undang menjadi milik lembaga legislatif.

Oleh karena pembentukan Undang-Undang ada pada lembaga legislatif. Maka, peranan lembaga legislatif yang sangat menentukan itu berarti peranan para wakil rakyat yang dipilih dan mewakili kepentingan rakyat yang berdaulat dari

\footnotetext{
${ }^{5}$ Jimly Asshiddiqie, Perihal Undang-Undang, Raja Grafindo Persada, Jakarta, 2010, h. 11.

${ }^{6}$ Bagir Manan, DPR DPD Dan MPR Dalam UUD 1945 BARU, Cet III, FH UII PREES, Yogyakarta, 2005, h. 22.
} 
mana kedaulatan Negara berasal sangat menentukan keabsahan dan daya ikat Undang-Undang itu untuk umum. ${ }^{7}$ Di sisi lain, rakyat ingin kehendaknya diketahui oleh para wakilnya, setiap peraturan yang dibuat harus mencerminkan keadilan yang selalu membela rakyat, maka dari hal itu rakyat yang berhak menentukan kebijakan-kebijakan kenegaraan yang akan mengikat mereka. Rakyat diberikan hak untuk memilih wakilnya sendiri agar berjalannya Negara sesuai dengan kehendak rakyat. Oleh sebab itu, setiap kebijakan haruslah dituangkan dalam UndangUndang sebagai produk legislatif (legislative act). ${ }^{8}$

Seperti yang dikemukakan di atas pembentukan Undang-Undang oleh lembaga legislatif juga sejalan dengan fungsi Dewan Perwakilan Rakyat yaitu fungsi legislasi yang telah banyak diketahui oleh masyarakat luas. Cabang kekuasaan legislasi juga mencerminkan kedaulatan rakyat dan di Indonesia fungsi legislasi dianggap yang paling penting di antara fungsi lainnya yang dimiliki oleh Dewan Perwakilan Rakyat. ${ }^{9}$

Pembuatan peraturan Perundang-Undangan dilakukan dengan menyusun program legislasi Nasional (Prolegnas). Hal ini diatur dalam Pasal 16 UndangUndang Nomor 12 Tahun 2011 Tentang Pembentukan Peraturan PerundangUndangan. Penyusunan Prolegnas dilaksanakan oleh DPR dan Pemerintah, dikoordinasikan oleh DPR melalui alat kelengkapan Dewan yang menangani khusus bidang legislasi. Prolegnas bertujuan untuk mewujudkan sistem hukum Nasional, Prolegnas memuat program pembentukan Undang-Undang dengan judul Rancangan Undang-Undang, materi yang diatur dan keterkaitannya dengan peraturan Perundang-Undangan lainnya. ${ }^{10}$ Penyusunan Prolegnas dilakukan dalam jangka menengah dan tahunan. Akan tetapi, Prolegnas tetap tidak bersifat mutlak jika timbul kebutuhan yang benar-benar objektif dan mendesak maka di tengah jalan dapat diajukan Rancangan Undang-Undang yang baru. Dengan demikian,

\footnotetext{
${ }^{7}$ Jimly Asshiddiqie, Op. Cit., h. 33.
}

${ }^{8}$ Ibid.,

${ }^{9}$ Jimly Asshiddiqie, Pengantar Ilmu Hukum Tata Negara, Jilid II, Sekretariat Jenderal Dan Kepaniteraan Mahkamah Konstitusi RI, Jakarta, 2006, h. 34.

${ }^{10}$ Lihat Pasal 19 Undang-Undang Nomor 12 Tahun 2011 Tentang Pembentukan Peraturan Perundang-Undangan. Lembaran Negara Republik Indonesia Nomor 82 Tahun 2011. 
Rancangan Undang-Undang dapat berasal dari daftar yang sudah ditentukan dalam Prolegnas dapat pula tidak berasal dari daftar Prolegnas asalkan memenuhi syarat. ${ }^{11}$

Dalam sistem ketatanegaraan di Indonesia pengajuan Rancangan UndangUndang tidak hanya berasal dari DPR namun Presiden juga dapat mengajukan Rancangan Undang-Undang seperti yang ditegaskan dalam UUD NRI 1945 Pasal 5 ayat 1 "Presiden berhak mengajukan Rancangan Undang-Undang". Ketentuan tersebut dipertegas dengan Undang-Undang Nomor 12 Tahun 2011 Tentang Pembentukan Peraturan Perundang-Undangan dalam Pasal 43 ayat 1 yang berbunyi, “Rancangan Undang-Undang dapat berasal dari DPR atau Presiden”. Hal ini memberi pengertian bahwa pembentukan Undang-Undang tidak dalam artian mutlak milik Dewan Perwakilan Rakyat sesuai dengan teori Pemisahan Kekuasaan. Namun Presiden juga mempunyai kewenangan dalam mengajukan Rancangan Undang-Undang sebagai lembaga yang menjalankan Undang-Undang. Sesuai ketentuan Pasal 43 ayat 3 Undang-Undang Nomor 12 Tahun 2011 Tentang Pembentukan Peraturan Perundang-Undangan yang menegaskan, "Setiap Rancangan Undang-Undang baik dari Presiden maupun DPR harus disertai Naskah Akademik".

Setiap Rancangan Undang-Undang yang diajukan oleh Presiden dilakukan oleh Menteri atau pimpinan lembaga nonkementerian, hal ini diatur dalam Pasal 47 Undang-Undang Nomor 12 Tahun 2011 Tentang Pembentukan Peraturan Perundang-Undangan. Dalam penyusunan Rancangan Undang-Undang, Menteri atau pimpinan lembaga Nonkementerian terkait membentuk panitia antar Kementerian dan/ atau antar Nonkementerian. Pengharmonisasian, pembulatan dan pemantapan konsep Rancangan Undang-Undang yang berasal dari Presiden dikoordinasikan oleh Menteri yang menyelenggarakan urusan pemerintahan di bidang hukum. ${ }^{12}$

Setiap Rancangan Undang-Undang yang berasal dari Presiden tetap harus sesuai dengan ketentuan Prolegnas terutama bentuk-bentuk yang menyangkut Undang-Undang, apabila Rancangan Undang-Undang yang disiapkan oleh Menteri

\footnotetext{
${ }^{11}$ Jimly Asshiddiqie, Op. Cit., h. 263-264.

${ }^{12}$ Alwi Wahyudi, Hukum Tata Negara Indonesia Dalam Perspektif Pancasila Pasca Reformasi, Pustaka Pelajar, Yogyakarta, 2012, h. 290.
} 
atau lembaga pemrakarsa dianggap cukup maka Rancangan Undang-Undang diajukan kepada pimpinan DPR dengan surat Presiden. ${ }^{13}$ Sesuai dengan ketentuan Pasal 50 Undang-Undang Nomor 12 Tahun 2011 Tentang Pembentukan Peraturan Perundang-Undangan yang menegaskan pengajuan Rancangan UU dilakuan dengan menyerahkan sura presiden terhadp pimpinan DPR. Menurut ketentuan tersebut surat dari Presiden harus memuat Menteri yang ditugasi mewakili Presiden dalam membahas Rancangan Undang-Undang, serta pembahasan akan dilakukan dalam jangka waktu paling lama 60 hari terhitung sejak surat dari Presiden diterima oleh DPR.

Adanya pengadaan memperbanyak naskah Rancangan Undang-Undang dalam jumlah yang diperlukan dimaksudkan untuk bisa disebarluaskan, hal ini bertujuan memberikan informasi dan/ atau memperoleh masukan dari masyarakat serta pemangku kepentingan, ${ }^{14}$ hal tersebut ditegaskan dalam Pasal 88 UndangUndang Nomor 12 Tahun 2011 Tentang Pembentukan Peraturan PerundangUndangan. Karena seperti yang disebutkan di atas kedaulatan berada pada rakyat.

Penggunaan sistem presidensiil berdasarkan teori Pemisahan Kekuasaan seperti ajaran Trias Politica Montesquieu yang dikenal banyak digunakan dalam sistem pemerintahan di dunia. Namun, dalam praktek ketatanegaraan Indonesia tidak mempertahankan sistem presidensiil murni dengan pemisahaan kekuasaan, ini dapat dilihat dalam pembahasan pembentukan Undang-Undang yang harus berdasarkan persetujuan bersama antara DPR dan Presiden, seperti yang ditegaskan dalam Pasal 20 ayat 2 yang berbunyi, "Setiap Rancangan Undang-Undang dibahas oleh Dewan Perwakilan Rakyat dan Presiden untuk mendapat persetujuan bersama". Oleh karena setiap rancangan yang tidak mendapatkan persetujuan bersama tidak akan bisa dijadikan Undang-Undang dan tidak bisa dibawa atau diajukan ke persidangan Dewan Perwakilan Rakyat. Persetujuan bersama dipersyaratkan secara mutlak karena nantinya Undang-Undang yang telah mendapat persetujuan bersama akan disahkan oleh Presiden seperti yang ditegaskan dalam Pasal 20 ayat 4 UUD NRI 1945.

\footnotetext{
${ }^{13}$ Ibid., h. 291.

${ }^{14}$ Ibid., h. 292.
} 
Pembahasan Rancangan Undang-Undang dilakukan oleh DPR dan Presiden yang diwakili Menteri yang ditugasinya dan DPD dapat ikut serta dalam pembahasan Rancangan Undang-Undang. Namun, DPD hanya dapat ikut serta dalam pembahasan Undang-Undang terkait dengan otonomi daerah, hubungan pusat dan daerah, pembentukan pemekaran dan penggabungan daerah, pengelolahan sumber daya alam dan sumber daya ekonomi lainya serta pertimbangan keuangan pusat dan daerah. Ketentuan tersebut diatur dalam Pasal 22D ayat 2 UUD NRI 1945. Dalam pembahasan Rancangan Undang-Undang dilakukan dengan dua tingkat, hal itu ditegaskan dalam Pasal 66 Undang-Undang Nomor 12 Tahun 2011 Tentang Pembentukan Peraturan Perundang-Undangan. Dalam pembahasan tingkat I yaitu meliputi kegiatan pengantar musyawarah, pembahasan daftar inventarisasi masalah dan penyampaian pendapat mini. Pembahasan tingkat II yaitu pengambilan keputusan dalam Rapat Paripurna. ${ }^{15}$

Dalam hal persetujuan bersama sangat jarang ada buku yang membahas tentang persetujuan bersama dan makna apa sebenarnya dari persetujuan bersama. Dalam penjelasan UUD NRI 1945 juga tidak dijelaskan makna persetujuan bersama. Hanya dalam naskah komprehensif disinggung sedikit tentang Pasal 20 ayat 2 UUD NRI 1945. Hal itu dimaksudkan agar sinergi pemerintah dan Dewan Perwakilan Rakyat bisa berjalan dengan baik. ${ }^{16}$

Persetujuan bersama merupakan kesepakatan untuk menentukan kebijakan berupa Undang-Undang, checks and balances merupakan prinsip yang dianggap mendasari hal ini, berbagai perwakilan fraksi saat pembahasan perubahan UUD NRI 1945 pada tahun 1999 banyak menyinggung tentang checks and balances, agar tidak terciptanya eksecutive heavy dengan mengembalikan fungsi sesungguhnya dari lembaga legislatif serta menyamakan lembaga-lembaga yang ada.

Dalam amandemen UUD NRI 1945 ingin mengembalikan fungsi sebenarnya dari beberapa lembaga Negara yang ada dengan mengedepankan prinsip checks and balances. Sehingga diputuskan lembaga pembentuk Undang-

\footnotetext{
${ }^{15}$ Lihat Undang-Undang Nomor 12 Tahun 2011 Tentang Pembentukan Peraturan Perundang-Undangan, Lembaran Negara Republik Indonesia Nomor 82 Tahun 2011.

16 Abdul Gofar et al., Naskah Komprehensif Perubahan Undang-Undang Dasar Negara Republik Indonesia Tahun 1945, Buku III, jilid 2, Sekretariat Jenderal dan Kepaniteraan Mahkamah Konstitusi, Jakarta, 2010, h. 666.
} 
Undang adalah Dewan Perwakilan Rakyat yang ditegaskan dalam Pasal 20 ayat (1) dan dengan persetujuan bersama yang ditegaskan dalam Pasal 20 ayat (2) UUD NRI 1945. Agar terciptanya sinergi antara legislatif dan eksekutif serta menunjukan kepatneran dalam menjalankan Negara Indonesia. Persetujuan bersama merupakan sebuah kesepakatan antara pemerintah dan Dewan Perwakilan Rakyat karena keduanya mempunyai hak yang sama dalam mengajukan Rancangan UndangUndang, sehingga diperlukan persetujuan keduanya dalam pembahasan dan pembentukan Undang-Undang.

Ketentuan persetujuan bersama menegaskan setiap pembahasan Rancangan Undang-Undang dilakukan bersama oleh DPR dan Presiden yang diwakili Menteri. Secara konstitusional disebutkan DPR dan Presiden, disebut Presiden karena Presidenlah yang menyelenggarakan pemerintahan dan memegang hak inisiatif mengajukan Rancangan Undang-Undang. ${ }^{17}$ Namun, biasanya Rancangan UndangUndang banyak yang datang dari pemerintah karena pemerintah lebih banyak mengetahui apa, mengapa, kapan suatu kebijakan perlu dituangkan dalam bentuk Undang-Undang, ${ }^{18}$ dari pada rancangan yang datang dari Dewan Perwakilan Rakyat.

Persetujuan bersama juga tidak bisa lepas dari Pancasila sebagai ideologi Negara. Dalam sila ke 4 yang menegaskan, "Kerakyatan yang dipimpin oleh hikmat kebijaksanaan dalam permusyawaratan perwakilan”. Ini berhubungan dengan demokrasi dan demokratisasi dalam kehidupan bermasyarakat, berbangsa dan bernegara dalam kerangka Negara hukum yang demokratis dan mempengaruhi Pasal 20 UUD NRI 1945. ${ }^{19}$ Dalam sejarah Nusantara banyak dikenal adanya kesepakatan dalam setiap pengambilan keputusan atau bisa disebut musyawarah, hal ini yang dituangkan dalam sila ke 4 Pancasila. Sehingga Indonesia dalam pembuatan Undang-Undang juga harus dilakukan dengan musyawarah, membahasnya bersam-sama atau bisa disebut dengan persetujuan bersama.

17 Bagir Manan, DPR DPD Dan MPR Dalam UUD 1945 Baru, Cet III, Fh-UII Press, Yogyakarta, 2005, h. 26-27.

18 Jimly Asshiddiqie, Perihal Undang-Undang, Raja Grafindo Persada, Jakarta, 2010, h. 289.

${ }^{19}$ Kokom Komalasari, Pendidikan Pancasila, Cet I, Lentera Cendikia, Surabaya, 2007, h. 170. 
Dari ketentuan persetujuan bersama atau sebuah kesepakatan antara Dewan Perwakilan Rakyat dan Presiden mirip dengan ketatanegaraan Amerika Serikat yang secara tegas memisahkan kekuasaan eksekutif (Presiden) dan legislatif (Kongres), namun Presiden tetap terkait dalam pembentukan Undang-Undang. ${ }^{20}$ Tetapi, di semua Negara pembahasan Rancangan Undang-Undang di dalam forum parlemen memang selalu melibatkan pemerintah. ${ }^{21}$ Tidak terkecuali juga di Indonesia, dalam pembentukan Rancangan Undang-Undang akan terus dibahas oleh Presiden dan DPR, dalam pembahasan itu bisa terjadi penambahan dan pengurangan ketentuan materi yang diatur di dalamnya. ${ }^{22}$ Setelah adanya pembahasan yang dilakukan bersama antara DPR dan Presiden, maka materi Rancangan Undang-Undang yang telah disepakati dalam rapat-rapat itu akan dibawa ke Rapat Paripurna DPR untuk mendapat pengesahan sebagai tanda dicapainya persetujuan bersama. ${ }^{23}$ Setelah disahkannya Rancangan UndangUndang itu dalam Rapat Paripurna DPR, secara materiil Rancangan UndangUndang itu dapat dikatakan final, dikatakan bersifat final karena materinya sudah tidak dapat lagi diubah oleh siapapun, termasuk oleh Presiden. ${ }^{24}$

Makna persetujuan bersama dapat dikatakan penting dalam pembahasan Rancangan Undang-Undang, karena dalam pembahasan Rancangan UndangUndang pasti ada proses tarik ulur (take and give) antara DPR dan Presiden dalam menyetujui atau menolak suatu materi yang terdapat dalam Rancangan UndangUndang, ${ }^{25}$ akhirnya dicapai persetujuan bersama antara DPR dan presiden yang kemudian dibawa ke Rapat Paripurna untuk disahkan sebagai tanda persetujuan bersama. Setelah adanya pengesahan yang menunjukan adanya persetujuan bersama, maka Rancangan Undang-Undang tersebut sudah bersifat materiil, daya ikat Rancangan Undang-Undang tersebut tinggal menunggu waktu pengesahan

\footnotetext{
${ }^{20}$ Bagir Manan, Op. Cit., h. 22.

${ }^{21}$ Jimly Asshiddiqie, Loc. Cit.

${ }^{22}$ Ibid., h. 42.

${ }^{23}$ Ibid.,

${ }^{24}$ Ibid., h. 43.

${ }^{25}$ Ibid., h. 46.
} 
secara formil oleh Presiden, untuk selanjutnya diundangkan sebagaimana mestinya dalam Lembaran Negara. ${ }^{26}$

Kata persetujuan bersama dalam hal ini tidak mesti harus setuju, Presiden dapat menolak atau menerima Rancangan Undang-Undang dari Dewan Perwakilan Rakyat, sebaliknya Rancangang Undang-Undang dari Presiden juga dapat ditolak oleh Dewan Perwakilan Rakyat atau hanya merubah materi yang ada dalam Rancangan Undang-Undang. Ditegaskan dalam Pasal 20 ayat 3 UUD NRI 1945 "Jika Rancangan Undang-Undang itu tidak mendapat persetujuan bersama, Rancangan Undang-Undang itu tidak boleh diajukan lagi dalam persidangan Dewan Perwakilan Rakyat masa itu”. Walaupun kewenangan pembentukan Undang-Undang ada pada DPR, namun DPR tidak bisa jalan sendiri tanpa persetujuan Presiden dalam pembentukan Undang-Undang. Tidak akan pernah ada Undang-Undang yang tercipta jika salah satu antara DPR atau Presiden tidak menyetujui Rancangan Undang-Undang. Jadi, persetujuan bersama mutlak disyaratkan dalam pembahasan Rancangan Undang-Undang.

Persetujuan bersama juga memberikan pengertian walaupun Indonesia menggunakan sistem pemisahan kekuasaan (separation of power) antara Dewan Perwakilan Rakyat dan Presiden, namun dapat juga disebut dengan pembagian kekuasaan (distribution of power). ${ }^{27}$ Hal ini dikarenakan DPR dan Presiden bersama-sama membentuk Undang-Undang. Menurut Bagir Manan mengenai persetujuan bersama antara DPR dan Presiden, tidak mungkin Rancangan UndangUndang menjadi Undang-Undang tanpa terlebih dahulu disetujui bersama oleh DPR dan Presiden, perlu ditambahkan, adanya persetujuan bersama dan keikut sertaan pemerintah bersama-sama DPR membahas Rancangan Undang-Undang merupakan salah satu petunjuk tidak dijalankannya separation of powers dalam sistem UUD NRI 1945 baik yang lama ataupun baru. ${ }^{28}$ Pernyataan berbeda dari Jimly Asshiddiqie yang menyebutkan bahwa Indonesia menganut sistem pemisahan kekuasaan berdasarkan prinsip checks and balances dengan catatan tidak dipahami dalam konteks ajaran Trias Politica Montesquieu.

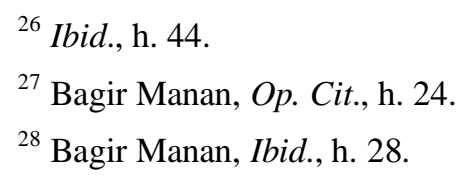


Dari uraian di atas dapat dipahami bahwa setiap Rancangan UndangUndang harus mendapat persetujuan bersama antara DPR dan Presiden, makna dari persetujuan bersama sendiri ialah sebuah kesepakatan antara DPR dan Presiden untuk menyetujui atau menyepakati Rancangan Undang-Undang untuk menjadi Undang-Undang, serta menunjukkan kemitraan dan keharmonisan antara lembaga eksekutif dan legislatif. Kenyataan ini menunjukan bahwa hubungan antar cabang kekuasaan itu tidak mungkin tidak saling bersentuhan, dan bahkan pemerintah dan DPR bersifat sederajat dan saling mengendalikan sesuai dengan prinsip checks and balances. $^{29}$

Walaupun kewenangan pembuatan Undang-Undang ada pada lembaga DPR, namun dengan adanya persetujuan bersama berarti itu tidak dalam artian mutlak dan DPR tidak bisa berjalan sendiri tanpa adanya keterlibatan pemerintah. Presiden mempunyai hak sebagai pemegang kekuasaan pemerintah yang nantinya menjalankan Undang-Undang untuk ikut membahas Rancangan Undang-Undang dan menyetujuinya bersama-sama dengan DPR. Dari kesepakatan yang terjalin antara DPR dan Presiden, Rancangan Undang-Undang bisa dibawa ke persidangan dan nantinya Rancangan Undang-Undang akan disahkan oleh Presiden sebagai Undang-Undang.

Setelah membahas tentang Pasal 20 ayat (2) UUD NRI 1945 yaitu terkait dengan persetujuan bersama. Maka, selanjutnya akan dibahas tentang politik hukum dari Pasal 20 ayat (5) yang merupakan penegasan tentang sahnya Rancangan Undang-Undang menjadi Undang-Undang walaupun tanpa tanda tangan presiden, karena ayat ini mengidentifikasikan adanya pertentangan dengan persetujuan bersama.

Politik hukum adalah legal policy atau garis (kebijakan) resmi tentang hukum yang akan diberlakukan baik dengan pembuatan hukum baru maupun dengan penggantian hukum lama, dalam rangka mencapai tujuan Negara. ${ }^{30}$ Ketika dalam memaknai sebuah Undang-Undang atau Pasal biasanya menggunakan penafsiran gramatikal. Namun, ketika dengan penafsiran gramatikal tetap tidak

\footnotetext{
${ }^{29}$ Jimli Asshiddiqie, Perkembangan dan Konsolidasi Lembaga Negara Pasca Reformasi, Sekretariat Jenderal Dan Kepaniteraan Mahkamah Konstitusi RI, Jakarta, 2006, h. 35.

${ }^{30}$ Moh. Mahfud MD, Politik Hukum Di Indonesia, Cet 4, Raja Grafindo Persada, Jakarta, 2011, h. 1 .
} 
dapat menemukan makna dari sebuah Undang-Undang atau Pasal yang ada dalam Undang-Undang maka sudah seharusnya menggunakan metode penafsiran historis, Agar mengetahui keinginan dari pembentuk Undang-Undang. Maka dalam hal ini bisa diketahui melalui politik hukum.

Pembahasan terkait dengan Pasal 20 ayat (5) sudah dapat diketahuissemenjak pembahasan amandemen pada tahun 1999. Tepatnya Rapat Panitia Ad Hoc III Badan Pekerja MPR ke-5 pada Senin, 11 Oktober 1999. ${ }^{31}$ Namun, finalisasi dari ayat (5) Rancangan UUD NRI 1945 baru disahkan pada amandemen ke dua yaitu tahun 2000. Dalam hal pembahasan rancangan Pasal 20 ayat (5) UUD NRI 1945 banyak anggota rapat yang melakukan perdebatan, diantaranya adanya ayat (5) dari Pasal 20 UUD merupakan sebuah penegasan dikarenakan Presiden telah memberikan persetujuan bersama. Jadi, tidak ada alasan lagi buat Presiden untuk menolak. Jadi Rancangan Undang-Undang yang telah mendapat persetujuan bersama tidak sia-sia dan berlaku walaupun Presiden tidak menandatangani. Disisi lain, Presiden dapat mengeluarkan Peraturan Pengganti Undang-Undang (PERPU). Jadi secara garis besar bukan tanpa alasan adanya Rncangan Undang-Undang tetap sah dan berlaku dalam jangka waktu tiga puluh hari semenjak Rancangan Undang-Undang itu dibahas walaupun tanpa tanda tangan presien. Sehingga dalam pembahasan amandemen yang kedua pada Rapat Paripurna ke-8 Sidang Tahunan MPR 2000, dilaksanakan pada 15 Agustus 2000 Pasal 20 ayat (5) UUD NRI 1945 disahkan. ${ }^{32}$

Dalam hal sahnya Undang-Undang Ada 5 (lima) tindakan hukum yang dilakukan untuk sahnya suatu Rancangan Undang-Undang menjadi UndangUndang yang mengikat untuk umum, tindakan hukum itu adalah pengesahan materiil, pengesahan formil, pengundangan, penerbitan dalam Lembaran Negara dan pemberlakuan. ${ }^{33}$ Pasal 20 ayat 5 UUD NRI 1945, ayat ini hanya merupakan penegasan karena Undang-Undang telah sah menjadi Undang-Undang ketika telah mendapat persetujuan bersama. Dalam bukunya Jimly Asshiddiqie mengatakan adanya pembatasan Rancangan Undang-Undang dan Undang-Undang adalah

\footnotetext{
${ }^{31}$ Abdul Gofar et al., op. cit., h. 728.

${ }^{32}$ Ibid., h. 1072

${ }^{33}$ Jimly Asshiddiqie, 2010, Perihal Undang-Undang, Raja Grafindo Persada, Jakarta, h. 291.
} 
tindakan pengesahan formil berupa pengundangan Undang-Undang itu dalam Lembaran Negara. Sejak diundangkan maka secara resmi naskah itu disebut Undang-Undang. ${ }^{34}$ Jimly Asshiddiqie mengemukakan ada tiga jenis Rancangan Undang-Undang yaitu Rancangan Undang-Undang yang belum dibahas bersama, Rancangan Undang-Undang yang dalam proses pembahasan dan Rancangan Undang-Undang yang telah mendapat persetujuan bersama oleh DPR dan Pemerintah yang telah disahkan dalam Rapat Paripurna DPR. ${ }^{35}$

Pasal 20 ayat 5 UUD NRI 1945 merupakan penegasan dari Rancangan Undang-Undang jenis ketiga yaitu yang telah mendapatkan persetujuan bersama antara DPR dan Presiden. Ketika Rancangan Undang-Undang tidak mendapat persetujuan bersama antara DPR dan Presiden, Rancangan Undang-Undang tidak akan pernah dibawa ke persidangan seperti yang ditegaskan dalam Pasal 20 ayat 3 UUD NRI 1945. Maka rancangan yang telah disetujui bersama tersebut secara materiil dapat dikatakan menjadi final karena materinya tidak dapat diubah oleh siapapun, sedangkan Pasal 20 ayat 5 merupakan pengesahan yang bersifat administratif. ${ }^{36}$ Secara materiil Rancangan Undang-Undang yang telah mendapat perstujuan bersama antara DPR dan Presiden, kualitas Rancangan Undang-Undang tersebut dianggap sebagai Undang-Undang meskipun secara formil belum mengikat untuk umum. ${ }^{37}$ Oleh karena itu, walaupun Presiden tidak mengesahkan Rancangan Undang-Undang yang telah disetujui bersama, maka Pasal 20 ayat 5 diberlakukan. Rancangan Undang-Undang tetap sah dan wajib diundangkan dan berlaku untuk umum.

Secara garis besar dapat dipahami kenapa ada Pasal 20 ayat 5 UUD NRI 1945, hal ini dikarenakan ketika Presiden tidak mengambil sebuah sikap untuk mengesahkan Rancangan Undang-Undang yang pada dasarnya telah disahkan dalam Rapat Paripurna yang menandai telah tercapainya persetujuan bersama antara DPR dan Presiden. Sehingga tidak ada alasan buat Presiden untuk tidak mengesahkan Rancangan Undang-Undang, pada dasarnya Presiden yang diwakili

\footnotetext{
${ }^{34}$ Ibid., h. 41.

${ }^{35}$ Ibid., h. 42.

${ }^{36}$ Ibid., h. 43.

${ }^{37}$ Ibid., h. 43-44.
} 
Menterinya telah ikut serta membahas bersama-sama Rancanagan Undang-Undang tersebut. Rancangan Undang-Undang yang telah disetujui dan disahkan merupakan Rancangan Undang-Undang yang telah sah dalam artian materiil dan keberlakuannya tinggal menunggu waktu saja. Pengesahan yang dilakukan Presiden merupakan pengesahan yang bersifat formil.

\section{KESIMPULAN}

Berdasarkan pembahasan maka dapat diambil kesimpulan sebagai berikut :

1. Yang dimaksud dengan persetujuan bersama dalam pembentukan UndangUndang adalah sebuah kesepakatan antara DPR sebagai lembaga legislasi dan Presiden sebagai pemegang kekuasaan pemerintahan untuk menyetujui atau menyepakati sebuah kebijakan berupa Undang-Undang. Persetujuan bersama antara DPR dan Presiden merupakan cerminan dari prinsip checks and balances. Artinya, persetujuan bersama dalam pembahasan dan pembentukan Undang-Undang menjadikan DPR sebagai legislator dan Presiden sebagai colegislator. Inilah makna sebenarnya dari persetujuan bersama DPR dan Presiden dalam pembentukan Undang-Undang.

2. Adanya Pasal 20 ayat 5 UUD NRI 1945 dikarenakan ketika Presiden tidak mengambil sebuah sikap untuk mengesahkan Rancangan Undang-Undang yang pada dasarnya Presiden telah ikut membahas Rancangan Undang-Undang bersama dengan DPR dan juga telah disahkan dalam Rapat Paripurna yang menandai telah tercapainya persetujuan bersama antara DPR dan Presiden. Jadi, Pasal 20 ayat 5 UUD NRI 1945 adalah hanya penegasan dari Pasal 20 ayat 2 UUD NRI 1945. Pengesahan Undang-Undang tanpa tanda tangan Presiden dilakukan dengan memberikan kalimat pengesahan "Undang-Undang ini dinyatakan sah berdasarkan ketentuan Pasal 20 ayat (5) Undang-Undang Dasar Negara Republik Indonesia Tahun 1945” dan dibubuhkan pada halaman terakhir Undang-Undang. Hal ini dilakukan sebelum pengundangan naskah Undang-Undang ke dalam Lembaran Negara Republik Indonesia.

\section{DAFTAR BACAAN}

Asshiddiqie, Jimly, Pengantar Ilmu Hukum Tata Negara, Jilid II, Sekretariat Jenderal Dan Kepaniteraan Mahkamah Konstitusi RI, Jakarta, 2006. 
, Perihal Undang-Undang, Raja Grafindo Persada, Jakarta, 2010.

Gofar, Abdul, et al., Naskah Komprehensif Perubahan Undang-Undang Dasar Negara Republik Indonesia Tahun 1945, Buku III, jilid 2, Sekretariat Jenderal Dan Kepaniteraan Mahkamah Konstitusi, Jakarta, 2010.

Komalasari, Kokom, Pendidikan Pancasila, Cet I, Lentera Cendikia, Surabaya, 2007.

Mahfud MD. Moh, Politik Hukum Di Indonesia, Cet 4, Raja Grafindo Persada, Jakarta, 2011.

Manan, Bagir, DPR DPD Dan MPR Dalam UUD NRI 1945 Baru, Cet III, Fh-UII Press, Yogyakarta, 2005.

Marzuki, Peter Mahmud, Penelitian Hukum, Kencana, Jakarta, 2005.

Wahyudi, Alwi, Hukum Tata Negara Indonesia Dalam Prespektif Pancasila Pasca Reformasi, Pustaka Pelajar, Yogyakarta, 2012. 